Serbia

\title{
A Hypocrite Called Rameau? Thoughts on the Similarities and Differences in the Treatment of Enharmonic in Rameau's Theories on Harmony vs. his Practice in his Harpsichord Composition ${ }^{1}$
}

\begin{abstract}
The name of Jean-Philippe Rameau (1683-1764) inevitably appears in the historical considerations of musical theorists. Rameau is considered the father of modern harmony, as well as one of the pioneers of the modern understanding of tonality. At the same time, he was almost certainly the most prominent figure in French music of the first half of the $18^{\text {th }}$ century. Along with the Couperin family, as a remarkably gifted composer for keyboard instruments, he is seen as the progenitor of the long tradition of French keyboard music, which can be traced all the way to our own time.

Such an interesting and multi-talented figure provides a very welcome opportunity for musicologists to assess the relationship between the theoretical and the creative; the empirical and the evanescent; and perhaps even the conscious and the subconscious.
\end{abstract}

Rameau the theorist obviously underwent a long evolution; however, this path was not always progressive and straightforward, but seems to have meandered and vacillated as he abandoned some of his ideas as the result of personal insecurity and (possibly) the harsh criticisms that mostly came from Jean-Jacques Rousseau (1712-1778). This led to obvious inconsistencies between the practice of Rameau the composer and the ideas of Rameau the theorist.

This paper offers a chronological comparison between Rameau's postulates about tonality theories and its subsystems (diatonic, chromatic and - above all enharmony) and his contemporaneous compositions for harpsichord, and will attempt to infer if and how much the composer adhered to his own postulates.

Keywords: Rameau, $18^{\text {th }}$ century, harpsichord, harmony, tonality, theory, practice

1 Based on the paper first presented at the Third International Conference on Historical Keyboard Music in Lisbon on June 9, 2018. 


\section{Introduction}

The name of Jean-Philippe Rameau (1683-1764) inevitably appears in the historical considerations of musical theorists. Rameau is considered the father of modern harmony, as well as one of the pioneers of the modern understanding of tonality. At the same time, he was almost certainly the most prominent figure in French music of the first half of the $18^{\text {th }}$ century. Along with the Couperin family, as a remarkably gifted composer for keyboard instruments, he is seen as the progenitor of the long tradition of French keyboard music, which can be traced all the way to our own time.

Rameau the theorist obviously underwent a long evolution; however, this path was not always progressive and straightforward, but seems to have meandered and vacillated as he abandoned some of his ideas as the result of personal insecurity and (possibly) the harsh criticisms that mostly came from Jean-Jacques Rousseau (1712-1778). This led to obvious inconsistencies between the practice of Rameau the composer and the ideas of Rameau the theorist.

Friedrich Wilhelm Marpurg (1718-1795), a music theorist from Berlin and a great follower of Rameau, bitterly attacked the ideas of the self-proclaimed opponent of the French composer, Johann Philipp Kirnberger (1721-1783). More specifically, Marpurgstrongly disagreed with his opponent's heavy use of implied, i.e. inaudible tones and harmonic functions in his theories on fundamental bass. Defending Rameau, Marpurg states that such a thing would have never occurred to the Frenchman as the leading theorist of his time (Grant, 1977: 334).

As convincing as this choice of wording might have seemed from an $18^{\text {th }}$ century viewpoint, it does have a vital flaw: it is fundamentally incorrect. In his Traité de l'harmonie (Treatise on Harmony; 1722), Rameau was very interested in the question of implied bass and treated it much more liberally than Kirnberger, leading Cecil Powell Grant to rightly observe that Rameau would have received a far better reception if Marpurg had not assumed the role of his advocate (Grant, 1977: 333).

This factual anecdote seems very illustrative of our perception of Rameau as a theorist: although he was certainly the pioneer of numerous elements of musical harmony and theory in general, many elements of his texts are being taken for granted. In fact, a number of Rameau's theories (particularly those in the field of tonality) are to be taken with a grain of salt because they reveal many of the author's vacillations and compromises, which left the French master open to harsh criticism and earned him a number of enemies.

So, if there are indeed inconsistencies and controversies in the works of Rameau the theorist, we must ask the following question: are there any differences between the writings of Rameau the theorist and the works of Rameau the composer? 
Inner inconsistencies in early harmonic works

Approaching Rameau as the key musical personality of France in the first half of the $18^{\text {th }}$ century is a remarkably complex task, because his theoretical and creative views were rooted in the philosophy and mathematics of his time. Generally, Rameau's understandings of acoustics, esthetics and philosophy were based on the views of René Descartes (1596-1650), who advocated the use of reason in music, and it was from him that the composer inherited the idea of nature imitation, albeit abstract rather than direct (Kintzler, 1999: 119-120). However, in his later works Rameau moved into the field of metaphysics, leading some of his supporters to renounce him (Kintzler, 1999: 40).

There is little doubt that Rameau's theories represent the foundations of the modern understanding of tonality and harmony in general. After almost a century of various treatises, which usually discussed the evolving musical language from a practico-mechanical, i.e. axiomatic point of view, Rameau's Traité was the first to offer a scholarly and theoretical basis for tendencies in music. The only other relevant surviving exception in this practice was the notable book L'harmonie universelle (Universal Harmony; 1636) by the French polymath Marin Mersenne (1588-1648), which was the first work to discuss in a scholarly manner the new creative tendencies in vocal and instrumental music, primarily questions pertaining to arrangement. However, from Rameau's first to the last treatises written several decades later, it is clear that his views on numerous notions and phenomena evolved over time, often even completely changing their paradigm. One of the most fundamental examples of this is corps sonore, as Rameau defines any object that vibrates and makes sounds (Kintzler, 1999: 99). Researching this, he earned the recognition of the scholarly community when he managed to define major harmonics. However, the composer-theorist was unhappy that his first attempts to discover minor harmonics had been unsuccessful. When he revisited this matter in his treatise Génération harmonique (Generation of Harmony; 1737), he did offer some results, but once again they failed to satisfy the scholarly community (Kintzler, 1999: 100). His insistence on these results and increasingly frequent deviations from the academic approach in the 1750s and 1760s distanced him from Jean-Baptiste le Rondd'Alembert (1717-1783), who had once been his most loyal ally (Kintzler, 1999: 39-40). Namely, until the 1750s, this encyclopédiste had often 'intervened' to defend Rameau's theories from Jean-Jacques Rousseau, but then became unwilling to continue doing so (Kintzler, 1999: 40). This intensified the feud between Rameau and Rousseau, a conflict discussed in more detail below.

However, Rameau's alleged inconsistencies and insecurities are perhaps most obviously reflected in his treatment of tonal genera, i.e. the diatonic, chromatic and - 
above all - enharmonic, with each of them requiring a special manner of tuning - many of which had yet to be accurately defined.

The development of the concepts of the diatonic, chromatic and enharmonic - in Rameau's time also known as tonal genera - can be traced back to Ancient Greece, and intellectual debates about these systems continued in the period of the Renaissance and the Baroque. In classical antiquity the diatonic referred to a system based on full intervals between the tones; the chromatic was based on semitones, and the enharmonic on quartertones. Modern discussions have partially redefined these concepts: while the diatonic and chromatic can generally be interpreted in a relatively similar way to our modern understanding of these concepts (although the acoustic frequency of the octave had yet to be strictly determined) the enharmonic could often include dozens of intervals within an octave; in view of the fact that this system came to be fully absorbed into the diatonic-chromatic system, this is bound to seem unacceptable today.

A conspicuous example of this is the well-known fact that special keyboard instruments with up to thirty-six tones in an octave were used in the $16^{\text {th }}$ and $17^{\text {th }}$ centuries to perform enharmonic compositions (Tiella, 1975: 7). Hence it seems paradoxical that works for keyboard instruments - previously widely used for a range of experiments - were one of the first to reduce the number of tonal means in practice. The incomplete nature of the tuning question can be said to have contributed a lot to the development of harpsichord literature in general.

In Traité, keeping up with his time, the aspect in which the author tried to be extremely practical was his perception of the system-language base. The major-minor tonality as such finally came to the fore, and Rameau was one of the first who tried to explain the implications of this system. However, his work never offers a specific definition of this new system and instead provides a phenomenological, axiomatic explanation in its opening chapters, offering a range of practical guidelines (Rameau, c17752:23-24). Of course, several chapters of this treatise discuss modulations; however, although they are here essentially given their modern meaning, there is virtually no typology for them (Rameau, c1775: 72-77). Rameau lists a few technical examples of ways to implement a modulation, almost all of which would be described as diatonic in modern terms (Rameau, c1775: 72-77). As noted by Cynthia Verba, it was not until Rameau's later works that previously differentiated terms such as 'chromatic' and 'modulation' grew to become closer (Verba, 1973: 69). However, to borrow Rameau's own words, the manner of their performance is "a matter of taste rather than rules" (Rameau, c1775: 74). An earlier chapter discusses so-called "harmonic modulation, when a harmonic progression is given to the bass," where Rameau in fact describes tonicization (Rameau, c1775: 25).

2 In this paper, I refer to the abridged English edition. 
In a bid to offer a comprehensive overview of contemporary trends in the production of active composers, the author caused a number of controversies and made many an opponent among his fellow theorists and composers, as well as philosophers and mathematicians. Drawing on practice and in defiance of previous trends in music theory, Rameau completely ignored the existence of the enharmonic genus, relying instead on the diatonic and chromatic (compare Rameau, c1775: 111).

However, a very important explanation seems to be absent from the book: more specifically, Rameau offers no hint of the manner in which instrument tuning is to be executed in the mathematico-acoustic sense - or which instruments, for that matter. As noted by Thomas Christensen, this was probably the reason that towards the end of his Nouveau système (New System; 1726) Rameau sketchily intimated that some modulations did indeed require a specific type of irregular temperament (Christensen, 2004: 201).

\section{The first example of practical inconsistencies:}

Nouvelles Suites de Pièces de Clavecin [New Suites of Harpsichord Pieces]

A very notable work among Rameau's works for keyboard instruments from this period is the cycle Nouvelles suites de pièces de clavecin (New Suites of Harpsichord Pieces; 1727). Its time of publication is particularly indicative: it was published merely five years after the Traité and just one year after Nouveau système. In a lucky turn of events for researchers, Rameau's introduction to the original edition includes his comments on the compositional and technical performance of most suites - a commentary that could be said to represent a mini-treatise in itself.

Another intriguing feature is the fact that the author does offer a definition of the enharmonic here, which is not the case in his treatises and theoretical works. He first attempts to explain that the human ear cannot recognize differences in semitones between the diatonic and the enharmonic genera, and that the use of quarter tone intervals - which is what the enharmonic genus had generally meant up until then - made little sense, adding that in the aptly named composition L'Enharmonique he tried to implement this phenomenon in the modern sense, naming it Diatonique enharmonique (diatonic enharmony) due to notation (Rameau, 1727: 1).

Several decades would pass before Rameau offered a theoretical elucidation of this. 

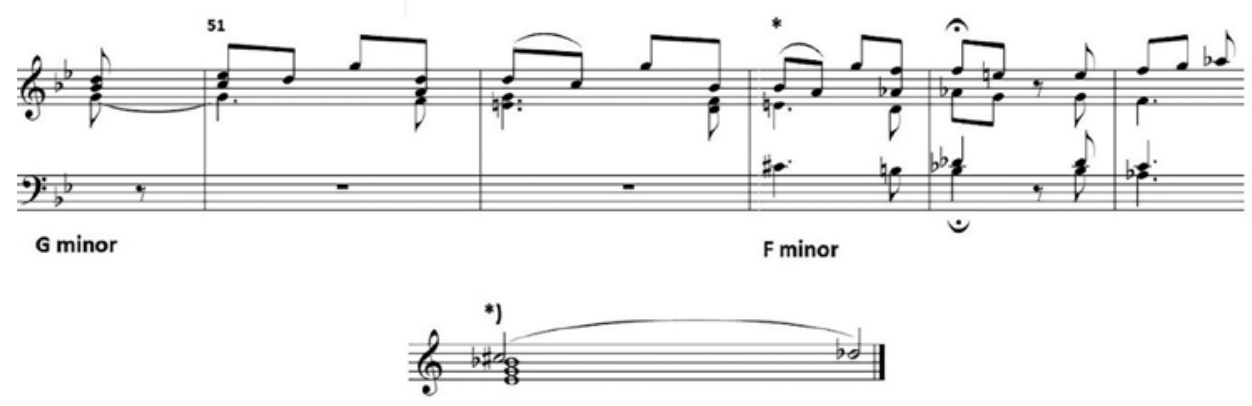

\section{Example No. 1: J.-P. Rameau: L'Enharmonique from Nouvelles suites de pièces de clavecin (1727), b. 51-55}

As for the title of this suite, in view of the content elaborated in the work, two points are particularly noteworthy, but we shall examine one of those. In the example No. 1, modulation does occur - from $\mathrm{G}$ minor to $\mathrm{F}$ minor. Another symptomatic feature is the link between the diminished seventh chord on the tone $\mathrm{C}$ sharp, which is to be understood as having the function of a diminished secondary chord of the dominant of $\mathrm{G}$ minor. However, it has no resolution and instead links to another diminished seventh chord on the tone B, which plays the role of a diminished secondary chord of the dominant F minor. Finally, it is given a very conditional 'resolution' into the diminished seventh chord of the seventh degree of the achieved key. What occurs here is certainly an enharmonic modulation on the first diminished seventh chord when $\mathrm{C}$ sharp becomes D flat, with the entire harmony acquiring the meaning of the seventh degree of $\mathrm{F}$ minor a whole bar before the composer (after the appearance of the diminished seventh chord on B) makes the appropriate notation. In addition, it should be noted that what occurs here is a modulation into a key that is not a closely related key, especially from the perspective of Baroque tonality. Rameau accords special attention to the example he provides in the introduction, elaborating his understanding of the tonal system; the following quote is a loose translation: "The effect experienced by the listener in the twelfth bar of the recapitulation (the $54^{\text {th }}$ bar in total) might not be to everyone's taste. However, once this initial repulsion dissipates, one should surrender to it and experience it in all of its beauty" (Rameau, 1727: 1).

Although these occurrences do not pose any analytical perceptional problems in the modern sense - what is more, it is possible, albeit much more difficult, to find a solution that does not entail the use of enharmonic modulation - we need to understand the context of the time when this composition was written. First, as already implied, at the time of publication of the entire cycle, equal temperament had yet to become a 3 Reproduction by the author of this paper. 
widely accepted system. Accordingly, no previous treatises - including Rameau's early theoretical works - had referred to enharmonic modulation as a way of changing the key. This in itself reveals how this discrepancy came to occur - a discrepancy between fairly liberal works in the field of theory of tonality and the even more liberal practical implementation in Rameau's works.

However, despite the importance of this example from the analytical and theoretical point of view, it is worth noting that it represents a unique occurrence in this period of Rameau's oeuvre. The remaining works in this collection are full of modulations, which could be - in modern terms -classed as diatonic and chromatic, but these examples of enharmonic changes do not appear anywhere else, and hence this could have been the reason for the composer's additional emphasis in the preface. ${ }^{4}$

\section{Paradigms in later theoretical works and their repercussions in compositions for the harpsichord}

Besides the enharmonic, another evolution - albeit much less controversial pertains to the matter of chromatics. In his early works, most notably Nouveau système, he accepted the possibility of the diatonic use of a non-modulating secondary dominants chain or, as Cynthia Verba terms it, a non-modulating diatonic chain of dissonances (Verba, 1973: 83). Discussing a later book called Observations sur notre instinct pour la musique (1754), Verba notes Rameau's acceptance of the possibility of forming a modulating secondary dominants chain in a single voice by using chromatic progression (Verba, 1973: 83). What Rameau had openly suggested in his Nouvelles suites received a theoretical elaboration only in 1737 in his next treatise Génération harmonique. As noted by Rehding and Heyes, in this work the author definitively embraces the concept of equal temperament and, as Rehding remarks, associates the enharmonic with the effects that appear in the aforementioned examples (Rehding, 2005: 150). Although this way of thinking was certainly applicable in keyboard music of the first half of the $18^{\text {th }}$ century, what gave rise to controversies was the author's implied view that this system could be applied to all genres and instruments. This was confirmed in the 1730s when Rameau began composing operas, heavily using the enharmonic in his own way. It was this change that ignited the fury of composer, encyclopédiste, music theorist and self-taught composer Jean-Jacques Rousseau and marked the beginning of their protracted and not particularly fruitful debate in journals and treatises about the rationale behind the global use of the new system that had previously been confirmed

4 It should be noted that Philippe Beaussant mentions the use of the enharmonic in the composition $\mathrm{La}$ Triomphante from the same cycle, probably alluding to the $31^{\text {st }}$ bar, but in this case this is not modulation but the enharmonic way of thinking, in line with the bass progression (A Sharp-A) (Rameau, 1727: 11; Beaussant, 1999: 132). 
solely in keyboard music. The two great thinkers went on to deeply polarize the music community of France and Europe on this matter, and the echoes of their bitter duel continued to resonate for another century (see Rehding, 2005).

On the theoretical level, it was not until 1750 that Rameau finally fully 'acknowledged' the enharmonic in one of his last books Démonstration du principe de l'harmonie, explaining its inner rules but completely subjugating this genus to the diatonic and chromatic. In this study he offers a detailed definition of diatonic enharmony and chromatic enharmony, which he had already intimated in his introduction to Nouvelles suites. To paraphrase Alexander Rehding simple explanation of this illustration, the first term relates to a phenomenon already encountered in the example of the suite L'Enharmonique, which already notates tones of varying solmization in semitone progression. (Rehding, 2005: 151) This author concludes that Rameau goes on to merely describe chromatic enharmony rather than offering a specific definition: it entails semitone progression with the notation of tones of an identical solmization (Rehding, 2005: 152).

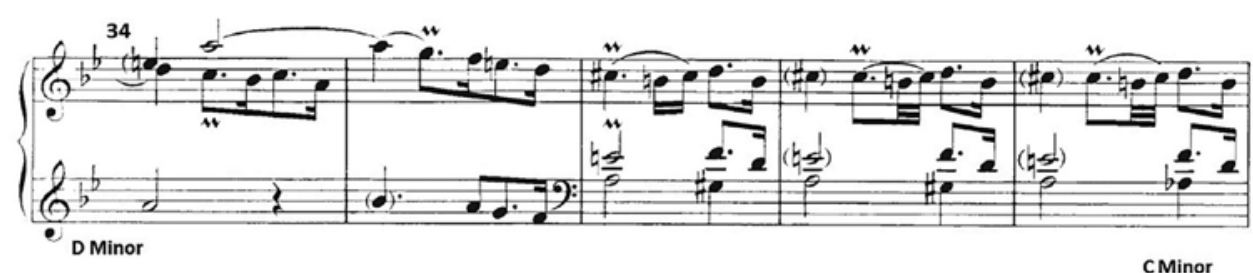

39

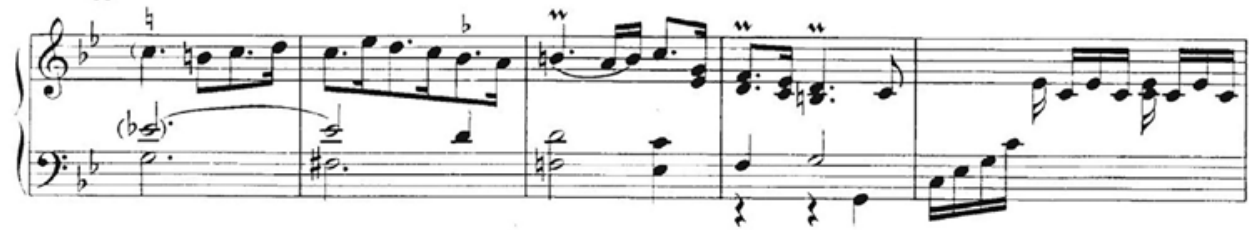

\section{Example No. 2: J.-P. Rameau: La Dauphine (1747), b. 34-43 (Reproduced from Rameau, 1959: 110)}

Let us consider one of his later harpsichord works: La Dauphine from 1747 and its unusual and very simple enharmonic modulation from $\mathrm{D}$ minor to $\mathrm{C}$ minor. ${ }^{5}$ In bars 36 and 37, on multiple occasions the composer, after the dominant, achieves a diminished seventh chord on $\mathrm{G}$ sharp which plays the role of a diminished seventh chord for the dominant. He does this again in bar 38, but instead of $A-G$ sharp, this

5 It should be noted that Rameau's authorship of this work has not been definitely established by music scholars; however, there is little evidence that it was composed by someone else. 
is notated as A - A flat; this is what Rameau calls chromatic enharmony, which is also the crucial difference to what he had done in Nouvelles suites. Now, out of nowhere, the second chord becomes the tonal six-four chord in $\mathrm{C}$ minor, and after three bars of cadence, this is confirmed.

\section{Aftermath}

After Rameau's death in 1764 it became clear that Rousseau would have the last word in their feud that had lasted for several decades. In an article in his Dictionnaire de musique (Dictionary of Music; 1768), the encyclopédiste was still convinced that the diatonic, chromatic and enharmonic must remain separated within a tonality, and that each of them should have its own rules for intervals, jumps and resolutions. As he had done many times throughout the previous decades, Rousseau launched another attack against Rameau due to the latter's modern approach to the use of these systems (above all the enharmonic). Like before, his criticism was primarily aimed at vocalinstrumental music, with Rousseau claiming that Rameau's harmonic effects had not been successful (Rousseau, 1768: 199).

In this regard, Rousseau also objected to the use of the enharmonic in the works of other composers, primarily in operas. As noted by Alexander Rehding, in one of his texts the famous encyclopédiste lambasted even Christoph Willibald Gluck (1714-1787), specifically criticizing the following segment from the opera Orfeo ed Euridice; please note the marked enharmonically identical tones which, according to Rousseau, should not appear within the same harmony (Rehding, 2005: 141-146):

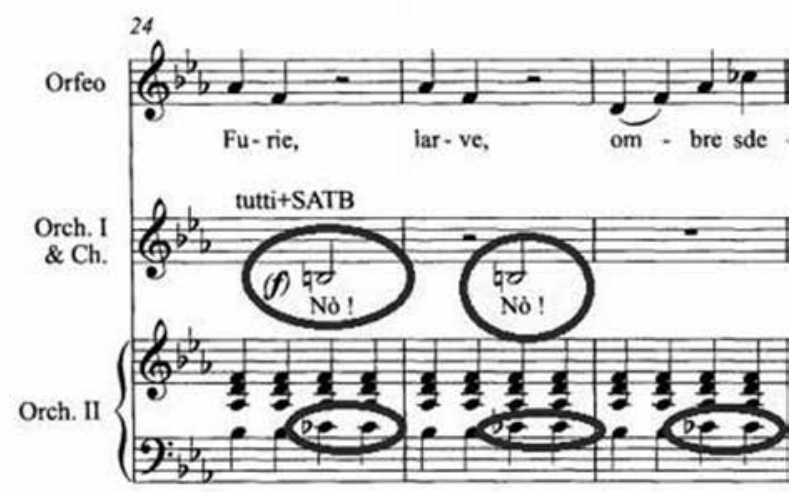

Example No. 3: C. W. Gluck: Orfeo ed Euridice (1762), 2nd act, 1st scene, b. 24-26 (Reproduced from Rehding, 2005: 143, additional markings by the author of this paper) 
So was Rameau a hypocrite? The answer to this question will depend on your perception of the matter: do you subscribe to a literal understanding of the author's claims in his theoretical works or do you choose to look at the big picture and see Rameau the theorist and Rameau the composer as a single creator? Most of the confusion resulting from these differing views stems from their secondary interpretations by Rameau's opponents and supporters alike. By the 1720s he had already established a system he would remain faithful to until the very end. For the most part, this system was indeed the result of the composer's own experience with keyboard instruments, above all the harpsichord.

He did not always openly list all of these elements in his theoretical works, but he did use them in practice (as illustrated by the example of Nouvelles suites) and commented on them extensively. Although it came several decades after his death, the eventual triumph of Rameau's principles supports the perception of him as a composer of very avant-garde convictions.

\section{REFERENCES:}

1. Beaussant, P. 1999. «Enharmonie». In Rameau de A à Z, 131-132.

2. Christensen, T. 2004. Rameau and Musical Thought in the Enlightenment. Cambridge University Press.

3. Eggington, T. 2014. The Advancement of Music in Enlightenment England: Benjamin Cooke and the Academy of Ancient Music. Suffolk: Boydell \& Brewer Ltd.

4. Grant, C. P. 1977. "The Real Relationship between Kirnberger's and Rameau's 'Concept of the Fundamental Bass"'. In Journal of Music Theory, 21 (2), 324-338.

5. Kintzler, C. 1999. "Corps Sonore". In Rameau de A à Z, 99-100.

6. Kintzler, C. 1999. «D’Alembert Jean Le Rond». In Rameau de A à Z, 39-40.

7. Kintzler, C. 1999. «Descartes René». In Rameau de A à Z, 119-120.

8. Mersenne, M. 1636. Harmonie Universelle, Contenant la Theorie et de la Pratique de la Musique, 1. Paris: Sebastien Cramoisy.

9. Rameau, J.-P. 1750. Démonstration du Principe de l'Harmonie, Servant à Base à Tout l'Art Musical Théorique et Pratique. Paris: Durand and Pissot.

10. Rameau, J.-P. 1737. Génération Harmonique, ou Traité de Musique Theorique et Pratique. Paris: Prault fils.

11. Rameau, J.-P. 1726. Nouveau Système de Musique Théorique, où on Découvre le Principe de Toutes les Règles Nécessaires à la Pratique, Pour Servir d'Introduction au Traité de l'Harmonie. Paris: Jean-Baptiste-Christophe Ballard.

12. Rameau, J.-P. 1727. Nouvelles Suites de Pièces de Clavecin. Paris: Chez L'Auteur.

13. Rameau, J.-P. 1959. Pièces de Clavecin. Kassel: Bärenreiter.

14. Rameau, J.-P. 1722. Traité de l'harmonie réduite à ses principes naturels.Paris: JeanBaptiste-Christophe Ballard.

15. Rameau, J.-P. c1775. Treatise of Music Containing the Principles of Composition. London: J. French.

16. Rehding, A. 2005. "Rousseau, Rameau, and Enharmonic Furies in the French Enlightenment”. In Journal of Music Theory, 49 (1), 141-180. 
17. Rousseau, J.-J. 1768. Dictionnaire de musique. Paris: Chez la Veuvne Duchesne.

18. Tiella, M. 1975. "The Archicembalo of Nicola Vicentino". In The English Harpsichord Magazine, 5 (1), 1-10.

19. Verba, E. C. 1973. "The Development of Rameau's Thought on Modulation and Chromatics". In Journal of American Musicological Society, 26 (1), 69-91.

\section{Licemer zvani Ramo? \\ Razmišljanja o sličnostima i razlikama u tretmanu enharmonije u Ramoovim teorijama o harmoniji nasuprot njegovim postupcima u kompozicijama za čembalo ${ }^{6}$}

Apstrakt: Ime Žan-Filipa Ramoa (1683-1764) neminovno se pojavljuje u istorijskim razmatranjima teoretičara muzike. Ramo se smatra ocem savremene harmonije, kao i jednim od pionira modernog razumevanja tonaliteta. Istovremeno, on je, gotovo sigurno, bio najistaknutija figura u francuskoj muzici prve polovine 18. veka. Zajedno sa porodicom Kupren, kao izuzetno nadaren kompozitor muzike za instrumente s dirkama, smatran je praocem duge tradicije francuske muzike za instrumente s dirkama, koja se može pratiti sve do našeg vremena.

Takva zanimljiva i višestruko talentovana figura pruža dobrodošlu priliku muzikolozima da procene odnos između teoretskog i kreativnog, iskustvenog i prolaznog, a možda čak i svesnog i nesvesnog.

Teoretičar Ramo je očigledno prošao dugu evoluciju; međutim, ovaj put nije uvek bio progresivan $\mathrm{i}$ jasan, ali, čini se da je vijugao i oscilirao, jer je napustio neke od svojih ideja zbog lične nesigurnosti i (verovatno) oštre kritike koja je, uglavnom, dolazila od Žan-Žaka Rusoa (1712-1778). To je dovelo do očiglednih nedoslednosti između postupaka Ramoa-kompozitora i ideja Ramoa-teoretičara.

Ovaj rad nudi hronološko poređenje Ramoovih postulata o teorijama tonaliteta i njegovih podsistema (dijatonike, hromatike $\mathrm{i}$ - pre svega - enharmonije) sa njegovim kompozicijama za čembalo, i nastojaće da zaključi da li se i koliko kompozitor pridržavao sopstvenih teorijskih postulata.

Ključne reči: Ramo, 18. vek, čembalo, harmonija, tonalitet

6 Na osnovu rada koji je prvi put predstavljen na „Trećoj međunarodnoj konferenciji o istorijskoj muzici za instrumente s dirkama" u Lisabonu, 9. juna 2018. godine. 